УДК 68.1 (470.51)

https://doi.org/10.32634/0869-8155-2021-344-1-144-146

Тип статьи: Краткий обзор

Type of article: Brief review

Колбина Л.М.,

Осокина А.С.

Удмуртский федеральный исследовательский центр УрО РАН. г. Ижевск, Российская

Федерация

lidakolbina@yandex.ru,

anastasia.osokina2017@yandex.ru

Ключевые слова: пчелиные семьи, пчеловодство, мёд, колхоз, Центральный Государственный архив Удмуртской республики

Для цитирования: Колбина Л.М., Осокина А.С. Оценка отрасли пчеловодства в годы Великой Отечественной войны на примере Большеучинского сельсовета Удмуртской АССР. Аграрная наука. 2020; 341 (9): 144-146.

https://doi.org/10.32634/0869-8155-2021-344-1-144-146

Конфликт интересов отсутствует

Lydia M. Kolbina, Anastasia S. Osokina

Udmurt Federal Research Center UB RAS Izhevsk, Russian Federation lidakolbina@yandex.ru, anastasia.osokina2017@yandex.ru

Key words: bee colonies, honey, beekeeping, kolkhoz, Central State Archive of the Udmurt Republic

For citation: Kolbina L.M., Osokina A.S. Estimation of the beekeeping industry during the Great Patriotic War on the example of the Bolsheuchinsky village soviet of the Udmurt ASSR. Agrarian Science. 2020; 341 (9): 144-146. (In Russ.)

https://doi.org/10.32634/0869-8155-2021-344-1-144-146

There is no conflict of interests

Оценка отрасли пчеловодства в годы Великой Отечественной войны на примере Большеучинского сельсовета
Удмуртской АССР

\title{
PEЗЮME
}

На основе архивных документов Центрального Государственного архива уР проведен анализ состояния пчеловодства Удмуртской АССР на примере Большеучинкого сельсовета - одного из крупных и стабильно развивающихся сельсоветов. Определено, что одними из основных медоносных культур высевали лен и гречиху. Посевы конопли также занимали незначительную площадь. Статистические архивные данные площадей посевов бобовых культур в хозяйствах Большеучинского c/c, показали, что за период ВОВ произошло снижение посевных площадей в 3,8 раз. Происходит ухудшение агрономического уровня, что отразилось на уровне сельскохозяйственного производства. В ряде колхозов оказались низкие урожаи, усилилась засоренность полей, произошли большие потери при уборке. Сокращение посевов происходило и по причине природно-климатических осложнений. В 1942 году было выделено максимальное количество мёда (1,4\% от собранного) по статье расходов «в фонд обороны Родины». Статья расходов на производственные нужды составила в годы ВОВ в среднем 15\%, исключение составил 1944 год 0,2\%. На протяжении всей ВОВ сохранялось распределение мёда в фонд помощи нуждающимся (инвалидам и на содержание дет. яслей). За военный период при практически стабильном количестве пчелиных семей в изучаемых хозяйствах, количество полученного мёда за изучаемые годы было нестабильно. Минимальный пик сбора мёда пришёлся на 1944 год - 181,37 кг из-за холодного лета (среднемесячная температура летних месяцев составила $\left.15-16^{\circ} \mathrm{C}\right)$. Вероятно, данный этап развития пчеловодства в годы ВОВ явился своего рода проверкой на прочность как самой системы организации труда на пасеке, так и профессионализм пчеловодов, которые прошли все испытания на «отлично».

\section{Estimation of the beekeeping industry during the Great Patriotic War on the example of the Bolsheuchinsky village soviet of the Udmurt ASSR}

\section{ABSTRACT}

Based on archival documents Of the Central state archive of the UR, the analysis of the state of beekeeping in the Udmurt ASSR was carried out on the example of Bolsheuchisnky village Council - one of the largest and steadily developing village councils. It was determined that flax and buckwheat were sown as one of the main honey crops. Cannabis crops also occupied a small area. Statistical archive data on the area of legume crops sown on farms of Bolsheuchinsky agricultural district showed that during the second world war there was a 3.8-fold decrease in sown areas. There is a deterioration in the agronomic level, which has affected the level of agricultural production. In a number of collective farms were low yields, increased infestation of fields, there were large losses during harvesting. The reduction of crops was also due to natural and climatic complications. In 1942, the maximum amount of honey (1.4\% of the collected amount) was allocated under the expenditure item "to the homeland defense Fund". In the years of the second world war, the item of expenditure on production needs averaged $15 \%$, with the exception of $1944-0.2 \%$. Throughout the second world war, honey was distributed to the Fund for assistance to the needy (disabled people and children). creches). During the war period, with an almost stable number of bee colonies in the studied farms, the amount of honey obtained during the studied years was unstable. The minimum peak of honey collection was in $1944-181.37 \mathrm{~kg}$ due to the cold summer (the average monthly temperature of the summer months was $15-16^{\circ} \mathrm{C}$ ). Probably, this stage of development of beekeeping during the second world war was a kind of test for the strength of both the system of labor organization in the apiary and the professionalism of beekeepers who passed all the tests with "excellent".

Поступила: 21 ноября

После доработки: 11 января

Принята к публикации: 13 января
Received: 21 november

Revised: 11 january

Accepted: 13 january 


\section{Введение}

Великая Отечественная война стала тяжелым испытанием для всего советского народа. Важным слагаемым Победы советского народа в ВОВ стал трудовой подвиг крестьянства [1]. Данное обстоятельство коснулось всех отраслей сельского хозяйства, не исключением стало и пчеловодство.

Цель исследований - анализ состояния колхозного пчеловодства Большеучинского сельского совета (c/c) в годы ВОВ и оценка его вклада в помощь фронту.

\section{Методика исследований}

Базу для историографии по вопросу изучения пчеловодства Большеучинского с/с составили в основном неопубликованные документы и годовые отчеты хозяйств, хранящиеся в Центральном государственном архиве Удмуртской Республики. В процессе работы использованы общенаучные методы, способы документального наблюдения, анализ архивных документов на основании методических рекомендаций «Формы, виды и способы статистического наблюдения» [2]. В результате статистического наблюдения получена объективная, сопоставимая, полная информация, позволяющая обеспечить научно-обоснованные выводы о характере и закономерностях развития изучаемого вопроса.

\section{Результаты исследований}

Большеучинский с/с Большеучинского района Удмуртской АССР на начало 1941 г. являлся крупным и стабильно развивающимся, в него входило 11 колхозов, из них 7 имели пасеки. В годы ВОВ благодаря оставшейся технической базе хозяйствам удалось сохранять большую часть посевных площадей, в т.ч. медоносные культуры. В колхозах Большеучинского с/с кроме злаковых культур и картофеля высевали медоносные культуры: гречиху, вику, лён, бобовые (горох, фасоль, чечевица и др.) и коноплю [3-9].

Из рисунка 1 видно, что из всех медоносных культур выделяются посевы льна, которые к концу ВОВ снизились. Площади посевов гречихи, наоборот, с начала войны увеличились, пик посевов достиг в 1943 году. В 1944 году выявлен незначительный спад посевов данной культуры в с/с и к концу войны достиг 139, 1 га. Выявлена тенденция относительно равномерного посева вики на протяжении всего военного времени, максимальный пик приходился на 1943 год - 15,57 га. Посевы конопли также занимали незначительную площадь. Статистические архивные данные площадей посевов бобовых культур в изучаемых хозяйствах, показали, что за период ВОВ произошло снижение посевных площадей в 3,8 раз. Происходит ухудшение агрономического уровня, что отразилось на уровне сельскохозяйственного производства В ряде колхозов оказались низкие урожаи, усилилась засоренность полей, произошли большие потери при уборке [10]. Сокращение посе- вов происходило и по причине природно-климатических осложнений [11].

В трудных условиях ВОВ, при нехватке горючего, тягловой и рабочей силы колхозы 4 года работали на Родину. Одной из важных статьей расходов мёда было «выделено по решению от собрания колхозников в фонд обороны Родины» [3-9], максимальное количество мёда на эту статью было выделено в 1942 г. - 13 кг (1,4\% от полученного) (табл.)

Расходы на общественное питание в 1941 году составили половину от общего количества полученного мёда, а в 1942 году расход мёда на эти нужды сократился, а в последующие годы составил 1,35-2,4\%. Статья расходов на производственные нужды составила в 1944 году - 0,2\%, высокий процент пришелся на 1942 и 1945 годы - 22,6 и 23,1\%, соответственно.

На протяжении всей ВОВ сохранялось распределение мёда в фонд помощи нуждающимся (инвалидам и на содержание дет. яслей). Однако максимальное количество мёда было выделено в 1945 году, что в 2,5 раза больше в сравнении с 1941 годом.

На 1 января 1941 года во всех хозяйствах Большеучинского с/с насчитывалось 66 пчелиных семей [3-9], от которых получили 533,8 кг мёда. Значительный вклад из всех хозяйств внёс колхоз «Горд-Шеп», который собрал 13,1 кг мёда с 1 пчелиной семьи.

Из рисунка 2 видно, что, несмотря на тяжелое состояние пчеловодства, состояние постепенно стабилизировалось и отмечена положительная динамика количества пчелиных семей. Это произошло благодаря Постановлению Совнаркома РСФСР № 125 от 14.03.1942 г. «О мероприятиях по развитию колхозного пчеловодства», а также постановлением Совета НК РСФСР № 546 от

Рис. 1. Посевные площади с/х культур в 1941-1945 годы, га

Fig. 1. Sown area of agricultural crops in 1941-1945, ha

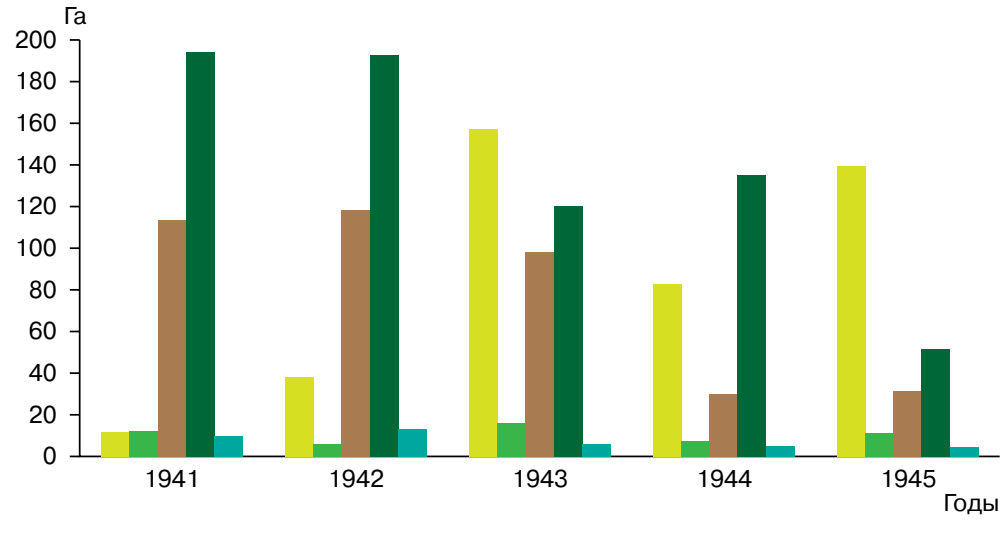

пречиха вика бобовые лен понопля

Таблица. Количество мёда, израсходованного на разные нужды, \%

Table. The amount of honey consumed for various needs, $\%$

\begin{tabular}{|c|c|c|c|c|c|}
\hline \multirow{2}{*}{ Расходы мёда на нужды } & \multicolumn{5}{|c|}{ Годы } \\
\hline & 1941 & 1942 & 1943 & 1944 & 1945 \\
\hline В фонд обороны Родины & - & 13 & 2,5 & 2,5 & 2,0 \\
\hline На общественное питание & 49,0 & 0,4 & 2,4 & 0 & 1,3 \\
\hline На производственные нужды & 11,4 & 22,6 & 17,9 & 0,2 & 23,1 \\
\hline Распределение по трудодням & 59,4 & 57,2 & 44,3 & 0,2 & 59,5 \\
\hline $\begin{array}{l}\text { Выделено в фонд помощи инвалидам } \\
\text { и др. и на содержании дет. яслей и } \\
\text { сирот }\end{array}$ & 9,2 & 3,6 & 0,8 & 0,1 & 23,1 \\
\hline
\end{tabular}


29.05.1943 г.: «на все время пасечных работ запретили использование пчеловодов колхозных насек и специалистов пчеловодных контор на работах, не связанных с пчеловодством».

За военный период при практически стабильном количестве пчелиных семей в изучаемых хозяйствах, количество полученного мёда за изучаемые годы было нестабильно. Минимальный пик сбора мёда пришёлся на 1944 г. - 181,37 кг из-за холодного лета (среднемесячная температура летних месяцев составила $15-16^{\circ} \mathrm{C}$ ) [12].

\section{Заключение}

На примере колхозов Большеучинского с/с Удмуртской АССР мы видим, что количество посевных площадей за военный период уменьшилось. Произошло перераспределение статей расходов полученного мёда на необходимые нужды, в т.4. в фонд обороны Родины. Вероятно, данный этап развития пчеловодства в годы ВОВ явился своего

\section{ЛИТЕРАТУРА}

1. Уваров, С.Н. Сельское население Удмуртии в годы ВОВ: Историко-демографический анализ. Вестник Удмуртского университета. Серия История и филология. 2014;(1): 64-72.

2. Формы, виды и способы статистического наблюдения (URL: http://www.grandars.ru/student/statistika/ vidy-statisticheskogo-nablyudeniya.html, дата обращения 15.10.2020). 83.

3. ЦГА УР. Фонд Р-567, оп. 1, д. 1676, л. 3, 9,11, 13, 21, 70,

4. ЦГА УР. Фонд Р-567, оп. 1, д. 1936, л. 79-82.

5. ЦГА УР. Фонд Р-567, оп. 1, д. 1937, л. 63, 130, 159.

6. ЦГА УР. Фонд Р-567,оп. 1, д. 1938, л. 49-52, л. 61-63.

7. ЦГА УР. Фонд Р-567, оп. 1, д. 1939, л.13-16 79-80 97-100.

8. ЦГА УР. Фонд Р-567, оп. 1 , д. 3789 , л. 3.

9. ЦГА УР Фонд Р-567, оп. 1, д. 3932, л. 13, 43, 54.

10. К новым успехам в сельском хозяйстве //Удмуртская правда, 1943, № 5 (6907): с. 1.

11. ЦГА УР Фонд Р-567. Оп. 1. Д. 3932. Л. 13, 43 - 43 об, 54.

12. Средние месячные и годовые температуры воздуха в Ижевске (http://www.pogodaiklimat.ru/history/28411.htm., дата обращения 5.09.2020)

\section{ОБ АВТОРАХ:}

Лидия Михайловна Колбина, д. с.-х. наук, главный научный сотрудник, lidakolbina@yandex.ru

Анастасия Сергеевна Осокина, к.б.н., старший научный сотрудник, Удмуртский федеральный исследовательский центр УpO PAH, anastasia.osokina2017@yandex.ru рода проверкой на прочность как самой системы организации труда на пасеке, так и профессионализм пчеловодов, которые прошли все испытания на «отлично».

\section{REFERENCES}

1. Uvarov, S.N. Sel'skoe naselenie Udmurtii $v$ gody VOV: Istorichesko-demograficheskij analiz [Rural population of Udmurtia during the Great Patriotic War: historical and demographical analysis]. Bulletin of Udmurt University. History and Philology Series. 2014;(1): 64-72. (In Russ.)

2. Formy, vidy i sposoby statisticheskogo nablyudeniya [Forms, types and methods of statistical observation] (http:// www.grandars.ru/student/statistika/vidy-statisticheskogonablyudeniya.html, data obrashcheniya 15.10.2020). (In Russ.)

3. CGA UR. Fond R-567, op. 1, d. 1676, I. 3, 9,11, 13, 21, 70, 83. (In Russ.)

4. CGA UR. Fond R-567, op. 1, d. 1936, I. 79-82. (In Russ.)

5. CGA UR. Fond R-567, op. 1, d. 1937, I. 63, 130, 159. (In Russ.)

6. CGA UR. Fond R-567,op. 1, d. 1938, I. 49-52, I. 61-63. (In Russ.)

7. CGA UR. Fond R-567, op. 1, d. 1939, I.13-16 79-80 97-100. (In Russ.)

8. CGA UR. Fond R-567, op. 1, d. 3789, I. 3. (In Russ.)

9. CGA UR Fond R-567, op. 1, d. 3932, I. 13, 43, 54. (In Russ.)

10. $\mathrm{K}$ novym uspekham $\mathrm{v}$ sel'skom hozyajstve [To new successes in agriculture] //Udmurtskaya pravda, 1943, № 5 (6907): 1. (In Russ.)

11. CGA UR Fond R-567. Op. 1. D. 3932. L. 13, $43-43$ ob, 54. (In Russ.)

12. Srednie mesyachnye i godovye temperatury vozduha $\checkmark$ Izhevske [Average monthly and annual air temperatures in Izhevsk] (http://www.pogodaiklimat.ru/history/28411.htm., data obrashcheniya 5.09.2020) (In Russ.)

\section{ABOUT THE AUTHORS:}

Lidia M. Kolbina, Doctor of Agricultural Sciences, Chief Researcher, lidakolbina@yandex.ru Anastasia S. Osokina, Cand. Sci. (Biology), Senior Researcher, anastasia.osokina2017@yandex.ru 